\title{
Have higher cigarette taxes in the United States discouraged smoking? A review of data from 1999-2013
}

\author{
Ben Musumba Womamili' , Adom Philip Gorrow²
}

\begin{abstract}
INTRODUCTION Cigarette smoking continues to be a leading cause of preventable morbidity and premature death in the United States. This study examined the impact of federal and state cigarette excise taxes on adult smoking between 1999 and 2013.

METHODS Data came from the National Health Interview Survey, Behavioural Risk Factor Surveillance System and Tax Burden on Tobacco. Analyses were done from 1999-2013, 20026 and 2009-13. Associations between cigarette taxes, prices and smoking were examined in several states based on cigarette tax: Missouri and Virginia (low tax), Florida, Nebraska and Nevada (median tax) and New York and Rhode Island (high tax).

RESULTS Smoking declined nationally from $22.8 \%$ (1999) to $19.0 \%$ (2013) with rates falling from $25.7 \%$ to $20.5 \%$ in men and $21.5 \%$ to $15.3 \%$ in women. Annual cigarette consumption (in millions) declined from 432,758 to 280,534 and per capita consumption from 1,621 cigarettes (1999) to 894 cigarettes (2013). Smoking declined across age, gender, race/ethnicity, education and poverty level in 2009-13 compared to 2002-6 with large reductions in states with higher cigarette taxes. Negative correlations between cigarette tax and smoking, and positive correlations between cigarette tax and price, were seen.

ConcLusions Higher cigarette taxes appear to have had a negative impact on smoking in the US. Our data suggest that states with higher cigarette taxes have lower smoking rates than states with lower taxes. Tax measures are however implemented as part of a comprehensive tobacco control package and further research is needed to assess the relative contribution of cigarette tax

on smoking reductions in the states examined.
\end{abstract}

\author{
AFFILIATION \\ 1 School of Health Sciences, \\ University of Canterbury, \\ New Zealand. \\ 2 Division of Population Health, \\ Health Services Research and \\ Primary Care, University of \\ Manchester, United Kingdom.

\section{CORRESPONDENCE TO Ben Musumba Wamamili. School of Health Sciences, University of Canterbury, \\ Christchurch, 8041 New Zealand. Email:benwamamili@yahoo.com}

\section{KEYWORDS}

Cigarette tax, cigarette price, tobacco use.

Received: 25 June 2016 Revised: 13 April 2017 Accepted: 19 April 2017

\section{INTRODUCTION}

Cigarette smoking continues to be a leading cause of preventable morbidity and premature death in the United States (US), resulting in more than 480,000 deaths annually - more than AIDS, alcohol, car accidents, illegal drugs, murders and suicides combined ${ }^{1}$. The economic costs of smoking are equally enormous with losses estimated at several hundred billion dollars annually ${ }^{1-3}$.

Smoking was an acceptable national pastime in the US until evidence of its deadly consequences was published in the landmark 1964 Surgeon General Report on smoking and health ${ }^{4}$. The Report's damning revelations heralded the beginning of a decades-long effort to curb the cigarette smoking epidemic. A number of measures and policies were implemented, including, but not limited to, health warnings on cigarette packs, restrictions on cigarette advertising and smoking in certain public spaces, prohibition of sale and distribution of tobacco products to minors, mass media education campaigns and raising taxes to force the price of cigarettes upward.

Over the past five decades, significant milestones have been reached in tobacco control with smoking prevalence and cigarette consumption more than halving across the country by 2012 compared to $1965^{1,5}$. State-level smoking rates have also declined remarkably but vary widely across the country ${ }^{6-8}$. This variation is thought to result from a number of variables, including differences in population demographics, levels of tobacco control programs and policies, variations in tobacco industry marketing and influence on state economies, and large differentials in state cigarette taxes and prices ${ }^{1,9,10}$.

Raising cigarette excise taxes is however controversial with proponents claiming higher taxes reduce consumption and improve public health, while opponents claim they have a negative impact on the economy. Overwhelming studies nevertheless support this intervention, noting that it increases 
the cost of cigarettes, prevents smoking initiation, promotes cessation, and reduces the prevalence and intensity of smoking among youth and adults ${ }^{1,10-20}$. Fewer people smoking means reduced risk of exposure to second-hand smoke (SHS) and associated illnesses, thus improved public health ${ }^{10}$.

This paper provides an overview of trends in smoking during a period of significant increments in cigarette excise taxes across the country, taking advantage of large variations in state cigarette taxes.

\section{METHODS}

\section{Data sources}

Data from the National Health Interview Survey (NHIS), Behavioural Risk Factor Surveillance System (BRFSS) and Tax Burden on Tobacco (TBT) from 1999-2013 were used.

The NHIS is a large-scale household interview survey of a representative sample of the US civilian noninstitutionalized population involving 75,000-100,000 individuals annually ${ }^{21}$. NHIS data contain annual estimates of persons aged 18 years or older who were current smokers, stratified by sex, age, race/ ethnicity, education and poverty status. NHIS data defined a current smoker as a person who reported smoking 100 cigarettes or more during their lifetime and at the time of the interview reported smoking every day or some days.

BRFSS is a collaborative project of the Centers for Disease Control and Prevention (CDC) and US States and Territories and is an ongoing data collection programme designed to measure behavioural risk factors for the adult population ${ }^{22}$. BRFSS completes more than 400,000 adult interviews each year, making it the largest continuously conducted health survey system in the world ${ }^{22}$. Data on tobacco use are state-specific with percentages weighted to population characteristics.

No direct contact with participants was necessary for this study. Both NHIS and BRFSS surveys however note that participants were required to provide informed consent at the time of data collection.

TBT reports have been published annually since 1949 with the cooperation of tobacco tax administrators in all States and the U.S. Department of Treasury's Alcohol and Tobacco Tax Trade Bureau ${ }^{5}$. The TBT 2014 Report contains data on federal cigarette tax, annual cigarette consumption (total and per capita) for selected years from 1865 to 2014, state cigarette tax during fiscal years ending June 30th from 1950 to 2014 and statespecific weighted average cigarette price per pack of cigarettes from 1st November 1954 to 2014.

State-specific data on cigarette price and smoking were collected in a small number of States, selected based on state cigarette excise tax and grouped in three categories: low tax
(Missouri and Virginia), median tax (Florida, Nebraska and Nevada) and high tax (New York and Rhode Island).

\section{Data analysis}

StatsDirect 3 (StatsDirect Ltd, 9 Bonville Chase, Altrincham, Cheshire WA14 4QA, UK) was used for all analyses. A significance level of $5 \%(P=0.05)$ was used and all $\mathrm{P}$ values are two-sided. Analyses were done in three phases: 1999-2013, 2002-6 and 2009-13. Most comparisons were made in smoking rates and cigarette taxes between 2002-6 and 2009-13: these 5 -year periods were chosen for their large differences in federal cigarette excise taxes per pack (\$0.39 in 2002-6 and \$1.01 in 2009-13). All variables of interest: federal cigarette tax, state cigarette tax, state-specific smoking rates and national smoking prevalence were continous quantitative variables.

Two sample t-test and associated confidence intervals (CI) were used to determine differences between two means when assumptions for this test were met. The non-parametric MannWhitney U test was used to compare equality of medians when the assumption of normality was not appropriate. Differences were considered statistically significant if CI did not overlap. One-way analysis of variance (ANOVA) was used to compare mean rates between three or more groups and Tukey's post hoc test used to confirm where differences occurred following significant ANOVA results. Two-sided $\mathrm{F}$ test results were used for comparison of variances.

In the few selected states, associations between cigarette price and smoking were determined in all tax categories while associations involving cigarette tax were determined only for states in the high tax category, since states in low and median tax categories had on average one tax increment over the study period. Linear regression models were used to examine unadjusted associations between cigarette taxes, cigarette prices and smoking rates.

\section{RESULTS}

Annual cigarette consumption declined significantly in 200913 compared to 2002-6: mean difference $=97,822$ million cigarettes (95\% CI: 69,658 to 125,985) and per capita cigarette consumption similarly declined significantly in the same period: mean difference $=402$ cigarettes $(95 \% \mathrm{CI}=283$ to 520$)$.

\section{Smoking by sex, age, race/ethnicity, education, and poverty status}

Smoking prevalence declined across gender, age, race/ethnicity, poverty line and education attainment, except in women with a General Educational Development (GED) qualification. Significant declines were however observed only in 18-24 
Table 1. Smoking prevalence by sex, age, race/ethnicity, education, and poverty status, in the United States, $2002-6$ and 2009-13

\begin{tabular}{|c|c|c|c|c|c|}
\hline \multirow[t]{2}{*}{ Characteristic } & \multirow[t]{2}{*}{ Sex } & \multicolumn{2}{|c|}{ Mean Median rates } & \multirow{2}{*}{$\begin{array}{c}\text { Mean Mediandifference } \\
\text { (with } 95 \% \text { CI) }\end{array}$} & \multirow[t]{2}{*}{ Pvalue } \\
\hline & & $2002-6$ & $2009-13$ & & \\
\hline \multicolumn{6}{|l|}{ Age } \\
\hline \multirow[t]{2}{*}{$18-24$} & M & 28.16 & 22.82 & $5.34(1.17$ to 9.51$)$ & 0.0184 \\
\hline & $\mathrm{F}$ & 21.52 & 15.86 & 5.66 (3.36 to 7.96$)$ & 0.0005 \\
\hline \multirow[t]{2}{*}{$25-44$} & M & 27.24 & 24.8 & $2.44(0.66$ to 4.22$)$ & 0.0134 \\
\hline & $\mathrm{F}$ & 21.88 & 19.18 & $2.7(0.69$ to 4.71$)$ & 0.0147 \\
\hline \multirow[t]{2}{*}{$45-64$} & M & 24.62 & 22.84 & $1.78(-0.16$ to 3.72$)$ & $\begin{array}{l}0.0676 \\
(0.0929)^{*}\end{array}$ \\
\hline & $\mathrm{F}$ & 19.84 & 18.82 & $1.02(-0.04$ to 2.08$)$ & 0.0581 \\
\hline \multirow[t]{2}{*}{$\geq 65$} & M & 10.1 & 9.7 & $0.3(-0.8$ to 2.9$)$ & 0.7581 \\
\hline & $\mathrm{F}$ & 8.32 & 8.18 & $0.14(-1.04$ to 1.32$)$ & $\begin{array}{l}0.7909 \\
(0.7969)^{*}\end{array}$ \\
\hline \multicolumn{6}{|l|}{ Race/Ethnicity } \\
\hline \multirow[t]{2}{*}{ White } & M & 24.3 & 22.5 & $1.8(-0.2$ to 3.2$)$ & 0.0794 \\
\hline & $\mathrm{F}$ & 20.62 & 18.88 & $1.74(0.50$ to 2.98$)$ & 0.0119 \\
\hline \multirow[t]{2}{*}{ Black } & M & 26.16 & 23.36 & $2.8(0.75$ to 4.86$)$ & 0.0138 \\
\hline & $\mathrm{F}$ & 18.14 & 16.4 & $1.74(-0.31$ to 3.79$)$ & 0.0856 \\
\hline \multirow[t]{2}{*}{ Hispanic } & M & 20.98 & 17.26 & $3.72(1.75$ to 5.67$)$ & 0.0024 \\
\hline & $\mathrm{F}$ & 10.64 & 8.44 & $2.2(1.00$ to 3.40$)$ & 0.0028 \\
\hline \multirow[t]{2}{*}{ Asian } & M & 18.34 & 15.66 & $2.68(0.80$ to 4.56$)$ & 0.0112 \\
\hline & $\mathrm{F}$ & 6.1 & 5.5 & $0.5(-1.4$ to 1.8$)$ & 0.754 \\
\hline \multicolumn{6}{|l|}{ Education level } \\
\hline \multirow[t]{2}{*}{ 0-12yrs, no diploma } & M & 31.2 & 29.92 & $1.28(-0.25$ to 2.81$)$ & 0.089 \\
\hline & $\mathrm{F}$ & 22.22 & 20.54 & $1.68(-0.40$ to 3.76$)$ & 0.0989 \\
\hline \multirow[t]{2}{*}{ GED } & M & 47.4 & 46.4 & $0.4(-5.8$ to 4.9$)$ & $>0.9999$ \\
\hline & $\mathrm{F}$ & 38.8 & 43.2 & $-3(-7.5$ to 2.7$)$ & 0.4206 \\
\hline \multirow[t]{2}{*}{ High school diploma } & M & 28.52 & 27.6 & $0.92(-0.54$ to 2.38$)$ & 0.1845 \\
\hline & $\mathrm{F}$ & 21.28 & 19.84 & $1.44(-0.27$ to 3.15$)$ & 0.0879 \\
\hline \multirow[t]{2}{*}{ Some college, no diploma } & M & 25.08 & 24.28 & $0.8(-1.24$ to 2.84$)$ & 0.3929 \\
\hline & $\mathrm{F}$ & 20.36 & 20.3 & $0.06(-1.22$ to 1.34$)$ & 0.9164 \\
\hline \multirow[t]{2}{*}{ Undergraduate } & M & 13.5 & 10.2 & $2.1(0.4$ to 3.7$)$ & 0.0317 \\
\hline & $\mathrm{F}$ & 9.92 & 8.86 & $1.06(-0.28$ to 2.40$)$ & 0.1044 \\
\hline \multirow[t]{2}{*}{ Graduate } & M & 7.6 & 5.84 & $1.76(0.72$ to 2.80$)$ & 0.0045 \\
\hline & $\mathrm{F}$ & 6.88 & 5.5 & $1.38(0.31$ to 2.45$)$ & 0.018 \\
\hline \multicolumn{6}{|l|}{ Poverty status } \\
\hline \multirow[t]{2}{*}{ At or above poverty line } & M & 23.82 & 20.08 & $3.74(2.15$ to 5.33$)$ & 0.0006 \\
\hline & $\mathrm{F}$ & 18.38 & 15.5 & $2.88(1.33$ to 4.43$)$ & 0.0027 \\
\hline \multirow[t]{2}{*}{ Below poverty line } & M & 34.02 & 33.74 & $0.28(-1.68$ to 2.24$)$ & 0.7504 \\
\hline & $\mathrm{F}$ & 28.18 & 25.88 & $2.3(-0.04$ to 4.64$)$ & $(0.7573)^{*}$ \\
\hline
\end{tabular}

${ }^{*}$ Figures in brackets show results of unequal variances test following a significant variance test ( $F$ test). Figures in bold Italics represent results of Mann-Whitney $U$ test generated by StatsDirect. 
and 25-44 year-olds (both gender), white women, black men, Hispanics (both gender), Asian men, men with undergraduate and graduate level education, women with graduate level education, and both men and women at or above the poverty line (Table 1).

\section{Smoking prevalence in selected States}

Smoking prevalence was lower in all examined states in 200913 compared to 2002-6 (Table 2) with significant declines seen predominantly in high and median tax states. In low tax states; mean smoking rates were significantly higher in Missouri compared to Virginia in both periods (2002-6: mean difference $=3.42$ (95\% CI: 0.61 to 6.23$)$ and 2009-13: mean difference $=$ 3.76 (95\% CI: 1.92 to 5.60). In median tax states; Nevada had significantly higher smoking rates than Nebraska in 2002-6 and higher than Florida in 2009-13. In high tax states; mean

\section{Table 2. Smoking prevalence in selected states by state} cigarette tax, in the United States, 2002-6 and 2009-13

\begin{tabular}{|c|c|c|c|c|}
\hline \multirow[t]{2}{*}{ State } & \multicolumn{2}{|c|}{ Mean median rates } & \multirow[t]{2}{*}{$\begin{array}{l}\text { Yean median } \\
\text { Difference (with } \\
95 \% \text { CI) }\end{array}$} & \multirow[t]{2}{*}{ P-value } \\
\hline & $2002-6$ & $2009-13$ & & \\
\hline \multicolumn{5}{|l|}{ Low tax } \\
\hline Missouri & 24.88 & 23.04 & $1.84(-0.63$ to 4.31$)$ & 0.1235 \\
\hline Virginia & 21.46 & 19.28 & $2.18(-0.10$ to 4.46$)$ & 0.0581 \\
\hline \multicolumn{5}{|c|}{ Median tax } \\
\hline Florida & 21.76 & 17.6 & $4.16(2.40$ to 5.92$)$ & 0.0006 \\
\hline Nebraska & 20.84 & 18.42 & $2.42(0.28$ to 4.56$)$ & 0.0314 \\
\hline Nevada & 23.94 & 20.74 & $3.2(0.60$ to 5.80$)$ & 0.0219 \\
\hline \multicolumn{5}{|l|}{ High tax } \\
\hline New York & 20.5 & 16.88 & $3.62(1.60$ to 5.64$)$ & 0.0033 \\
\hline $\begin{array}{l}\text { Rhode } \\
\text { Island }\end{array}$ & 21.02 & 17.12 & $3.9(1.41$ to 6.39$)$ & 0.0068 \\
\hline
\end{tabular}

smoking rates were higher in Rhode Island in both periods but were not significantly different from New York (2002-6: mean difference $=0.52$ (95\% CI: -1.72 to 2.76$)$ and 2009-13: mean difference $=0.24$ (95\% CI: -2.05 to 2.53$)$.

\section{State cigarette tax, price and smoking prevalence}

Results showed negative correlations between cigarette tax and smoking prevalence in both New York (prevalence $=-1.50 *$ Tax $+22.57, r^{2}=0.60,95 \%$ CI for $r=-0.92$ to -0.43$)$ and Rhode Island (prevalence $=-2.32 *$ Tax $+24.86, r^{2}=0.78,95 \%$ CI for $r$ $=-0.96$ to -0.67 ). Positive correlation between cigarette tax and price was seen in both states: New York (price $=1.80 *$ Tax + $2.96, r^{2}=0.91,95 \%$ CI for $r=0.87$ to 0.99$)$ and Rhode Island $\left(\right.$ price $=1.66 *$ Tax $+2.44, r^{2}=0.96,95 \%$ CI for $r=0.93$ to 0.99).

Multiple linear regression models for associations between state cigarette tax, price and smoking rates in New York and Rhode Island showed significant $\mathrm{F}$ for overall regressions: New York $(\mathrm{F}=14.31, \mathrm{P}=0.0007)$ and Rhode Island $(\mathrm{F}=28.51, \mathrm{P}=$ $<0.0001$ ), indicating that state cigarette tax or cigarette price, or both, were associated with smoking in these states.

Negative correlations between state cigarette price and smoking were observed in all states examined (Table 3). These relationships were generally linear with few outliers likely due to cigarette price increases that accompanied federal cigarette excise tax increments in 2000, 2002 and 2009.

\section{DISCUSSION}

Adult smoking declined substantially in the United States between 1999 and 2013, a period characterized by significant raises in cigarette excise taxes at federal and state levels. Large reductions in cigarette consumption and smoking in men and women of all ages and socioeconomic backgrounds, and men at

Table 3. Simple linear regression models of Cigarette Price Vs Smoking Prevalence in selected states, $1999-2013$

\begin{tabular}{|c|c|c|c|c|c|}
\hline State & Regression equation & SE of slope & $r($ with $95 \%$ CI $)$ & $r^{2}$ & P-value \\
\hline \multicolumn{6}{|l|}{ Low Tax } \\
\hline Missouri & S.Prev $=-2.04 *$ Price +32.38 & 0.54 & $-0.72(-0.90$ to -0.33$)$ & 0.52 & 0.0025 \\
\hline Virginia & S.Prev $=-1.37 *$ Price +25.76 & 0.55 & $-0.57(-0.84$ to -0.08$)$ & 0.32 & 0.0276 \\
\hline \multicolumn{6}{|l|}{ Median Tax } \\
\hline Florida & S.Prev $=-1.50 *$ Price +26.61 & 0.34 & $-0.77(-0.92$ to -0.43$)$ & 0.60 & 0.0007 \\
\hline Nebraska & S.Prev $=-1.34 *$ Price +26.80 & 0.45 & $-0.64(-0.87$ to -0.18$)$ & 0.40 & 0.0109 \\
\hline Nevada & S.Prev $=-3.35 *$ Price +38.40 & 0.62 & $-0.83(-0.94$ to -0.55$)$ & 0.69 & 0.0001 \\
\hline \multicolumn{6}{|l|}{ High Tax } \\
\hline New York & S.Prev $=-0.86 *$ Price +25.21 & 0.16 & $-0.84(-0.94$ to -0.57$)$ & 0.70 & 0.0001 \\
\hline Rhode Island & S.Prev $=-1.27 *$ Price +27.47 & 0.25 & $0.82(-0.94$ to -0.53$)$ & 0.67 & 0.0002 \\
\hline
\end{tabular}

S.Prev: Smoking Prevalence. 
all educational levels were seen, as were declines in smoking in most states.

Numerous studies have demonstrated the impact of cigarette price on smoking and concluded that higher cigarette taxes lead to higher prices that discourage smoking initiation, promote cessation, prevent relapse among former smokers, and lower the number of cigarettes consumed by continuing smokers ${ }^{1,10-20,23-26}$. Higher taxes also provide governments with finances that can be used to implement other proven tobacco control policies that further reduce smoking and improve public health $\mathrm{h}^{10,11,17,24,26}$.

Our results reveal that despite fewer people smoking at all ages and gender, significant declines were observed only in those aged under 45 years. These support general consensus that smoking behaviour of younger people is more pricesensitive, both because they have less disposable income and because they are typically less addicted than older smokers ${ }^{17,27-30}$.

Findings of greater reductions in smoking among Hispanics, White females, Black males and Asian males when looking at smoking rates against race/ethnicity are consistent with those of a previous study by Farrelly and Bray ${ }^{31}$ that looked at price responsiveness among White, Black and Hispanic adults and found smoking in Hispanics and Blacks to be more affected by price increase than in White adults.

Our results cast some doubts to popular expectations that smokers with lower education have smaller price elasticities than smokers with higher education ${ }^{32}$, and would be expected to change their smoking behaviour to a greater extent when prices rise. This counterintuitive correlation between higher education and greater declines in smoking could be as a result of tobacco industry offering targeted price-subsidizing promotions that segment the market (i.e. lower prices in poor neighbourhoods) and increased polytobacco use among smokers in this group ${ }^{1,30,33,34}$. Observed variations could be related to differences in receptivity towards tobacco-related health messages and understanding of the health risks of smoking ${ }^{35}$.

Our results are also inconsistent with previous research that found people in lower socioeconomic status reduced cigarette consumption by greater margins following cigarette tax increase than their more affluent counterparts ${ }^{17,29}$. It is known that many smokers seek alternative sources of lower priced cigarettes in response to price increase instead of quitting or reducing consumption ${ }^{1,10,36}$. They do this by obtaining cigarettes in states with lower taxes, purchasing no-to-low taxed products over the internet or at Native American reservations, purchasing no-to-low taxed cigarettes on the black market, smuggling cheap products across national and international borders, switching to discounted brands or making their own cigarettes (roll-your-own), among other strategie $^{26,36-42}$. It is possible that a large proportion of lowincome smokers may have employed these tactics.

Large disparities in state cigarette excise taxes and smoking were evident with significant reductions in smoking predominantly in states with higher taxes (Table 2). Smoking rates differed even among states in the same tax category, indicating influence of factors besides taxes. Such confounders may include differences in state; population demographics, levels of tobacco control programs and policies, and tobacco industry marketing and promotion activities ${ }^{1,9,10}$. The tobacco industry is known to wield enormous powers on politicians, governments and decision makers ${ }^{43,44}$. This is highlighted by the disproportionately low cigarette excise taxes and high smoking prevalence in major tobacco-growing states ${ }^{19,45}$.

The observed negative correlations between cigarette tax and smoking, and positive correlations between cigarette tax and price strengthen existing arguments that sustained tax increments would result in sustained higher prices and lead to persistent declines in smoking, with a healthier population and reduced healthcare costs. Tax increases however, do not always lead to higher prices. Tobacco industry often step up pricelowering interventions to off-set tax increases and maintain high consumption $^{30,46,47}$.

\section{Strengths and limitations}

Our study has a number of strengths. Data came from sources that employed robust sampling and data collection methodologies. Data covered a period of 15-years, which is much longer than most other previous studies in this area. Analyses were done over a 15-year period as a single block and in two nested 5-year periods (2002-6 and 2009-13) during which federal cigarette taxes varied widely.

Our limitations include lack of data on cigarette sales tax, local/municipal taxes and temporary price reductions. Added together, these taxes could substantially increase the tax burden on smokers, while price reductions could minimise the impact higher taxes would otherwise have on reducing smoking. Secondly, most analyses compared smoking in 2002-6 with 2009-13, interpreted by the statistical software as sample sizes of $5(n=5)$. This increased the risk of underestimating some effects. Thirdly, data were not controlled for potential confounders, such as major policy and environmental changes that occurred during the study period. Higher cigarette taxes were not implemented in isolation, rather as part of a comprehensive tobacco control package. Finally, this study resulted from a Master's in Public Health (MPH) dissertation project that did not require primary data collection, hence reliance on secondary data sources. 


\section{CONCLUSIONS}

Higher cigarette excise taxes appear to have had a substantial negative effect on smoking in the US between 1999 and 2013. Our data suggest that states with higher cigarette taxes have higher cigarette prices and lower smoking rates than states with lower cigarette taxes. Tax measures are however not implemented in isolation, but as part of a comprehensive tobacco control package that includes restrictions on tobacco access to minors, smoking bans in workplaces and public spaces, mass media education campaigns, subsidised smoking cessation treatments, amongst other proven strategies. Further research is therefore needed to assess the relative contribution of cigarette tax on smoking reductions in the examined states.

\section{REFERENCES}

1. U.S. Department of Health and Human Services, 2014. The Health Consequences of Smoking: 50 Years of Progress. A Report of the Surgeon General. Atlanta, GA: U.S. Department of Health and Human Services, Centers for Disease Control and Prevention, National Center for Chronic Disease Prevention and Health Promotion, Office on Smoking and Health.

2. Xu, X. et al., 2015. Annual Healthcare Spending Attributable to Cigarette Smoking. American Journal of Preventive Medicine, 48(3), pp. 326-33.

doi:10.1016/j.amepre.2014.10.012.

3. CDC, 2008. Smoking-attributable mortality, years of potential life lost, and productivity losses - United States, 2000-2004. Morbidity and Mortality Weekly Report (MMWR), 57(45), pp. 1226-1228.

4. U.S. Department of Health, Education, and Welfare, 1964. Smoking and Health: Report of the Advisory Committee of the Surgeon General of the Public Health Service, Washington, DC: U.S. Department of Health, Education, and Welfare.

5. Orzechowski and Walker, 2014. Tax Burden on Tobacco: Historical Compilation 2014, Arlington, VA: Orzechowski and Walker.

6. CDC, 2011. Adult Smoking in the US infographic. Available at: http://www.cdc.gov/vitalsigns/adultsmoking/infographic.html (accessed 6 April 2017).

7. CDC, 2010. State-Specific Prevalence of Cigarette Smoking and Smokeless Tobacco Use Among Adults - United States, 2009. Morbidity and Mortality Weekly Report (MMWR), 59(43), pp. 1400-1406.

8. King, B. A., Dube, S. R. \& Tynan, M. A., 2012. Current Tobacco Use Among Adults in the United States: Findings From the National Adult Tobacco Survey. American Journal of Public Health, 102(11), pp. e93-e100. doi: 10.2105/AJPH.2012.301002.

9. Farrelly, M. C., Pechacek, T. F., Thomas, K. Y. \& Nelson, D., 2008. The impact of tobacco control programs on adult smoking. American Journal of Public Health, 98(2), pp. 304-309. doi: 10.2105/AJPH.2006.106377.

10. International Agency for Research on Cancer, 2011. Effectiveness of Tax and Price Policies for Tobacco Control. IARC Handbooks of
Cancer Prevention, Vol. 14. Lyon (France): International Agency for Research on Cancer.

11. World Health Organization, 2009. WHO Report on the Global Tobacco Epidemic, 2009: Implementing smoke-free environments, Geneva: World Health Organization.

12. Hu, T.-w., Keeler, T. E., Sung, H.-y. \& Barnett, P. G., 1995. The impact of California anti-smoking legislation on cigarette sales, consumption, and prices. Tobacco Control, 4(suppl 1), pp. S34-S38.

13. Morley, C. P. \& Pratte, M. A., 2013. State-Level Tobacco Control and Adult Smoking rate in the United States. Journal of Public Health Management and Practice, 19(6), pp. E20-E27. doi:10.1097/phh.0b013e31828000de.

14. Cavazos-Rehg, P. A. et al., 2012. Differential effects of cigarette price changes on adult smoking behaviours. Tobacco Control, 23(2), pp. 113-138. doi:10.1136/tobaccocontrol-2012-050517.

15. Sung, H.-Y. et al., 2005. A Major State Tobacco Tax Increase, The Master Settlement Agreement, And Cigarette Consumption: The California Experience. American Journal of Public Health, 95(6), pp. 1030-1035. doi:10.2105/ajph.2004.042697.

16. Chaloupka, F. J., Straif, K. \& Leon, M. E., 2010. Effectiveness of tax and price policies in tobacco control. Tobacco Control, 20(3), pp. 235-238. doi:10.1136/tc.2010.039982.

17. Chaloupka, F.J., Yurekli, A. \& Fong, G. T., 2012. Tobacco taxes as a tobacco control strategy. Tobacco Control, 21(2), pp. 172-180. doi:10.1136/tobaccocontrol-2011-050417.

18. Jha, P., 2000. The economics of global tobacco control. BMJ, 321(7257), pp. 358-361. doi:10.1136/bmj.321.7257.358.

19. Centers for Disease Control and Prevention, 2009. Federal and state cigarette excise taxes - United States, 1995-2009. Morbidity and Mortality Weekly Report (MMWR), 58(19), pp. 524-527.

20. Gilbert, A. \& Cornuz, J., 2003. Which are the most effective and cost-effective interventions for tobacco control?, Copenhagen: WHO Regional Office for Europe (Health Evidence Network).

21. CDC, 2015. About the National Health Interview Survey. Available at: http://www.cdc.gov/nchs/nhis/about_nhis.htm (accessed 6 April 2017).

22. CDC, 2014. About BRFSS. Available at: http://www.cdc.gov/brfss/ about/index.htm. (accessed 6 April 2017).

23. U.S. Department of Health and Human Services, 2000. Reducing Tobacco Use: A Report of the Surgeon General. Atlanta, Georgia: U.S. Department of Health and Human Services, Centers for Disease Control and Prevention, National Center for Chronic Disease Prevention and Health Promotion, Office on Smoking and Health.

24. World Health Organization, 2008. WHO Report on the Global Tobacco Epidemic, 2008: The MPOWER Package. Geneva, World Health Organization.

25. Institute of Medicine, 2007. Ending the tobacco problem: A blueprint for the nation. Washington, DC: The National Academies Press.

26. Farrelly, M. C., Nimsch, C. T. \& James, J., 2003. State Cigarette 
Excise Taxes: Implications for Revenue and Tax Evasion, Report prepared for the Tobacco Technical Assistance Consortium. Available at: http://www.rti.org/sites/default/files/resources/8742_Excise_ Taxes_FR_5-03.pdf. (accessed 6 April 2017).

27. DeCicca, P. \& McLeod, L., 2008. Cigarette taxes and older adult smoking: Evidence from recent large tax increases. Journal of Health Economics, 27(4), pp. 918-929. doi:10.1016/j.jhealeco.2007.11.005.

28. Carpenter, C. \& Cook, P. J., 2008. Cigarette taxes and youth smoking: New evidence from national, state, and local Youth Risk Behavior Surveys. Journal of Health Economics, 27(2), pp. 287299. doi:10.1016/j.jhealeco.2007.05.008.

29. Biener, L., Aseltine, R. H., Cohen, B. \& Anderka, M., 1998. Reactions of Adult and Teenaged Smokers to the Massachusetts Tobacco Tax. American Journal of Public Health, 88(9), pp. 1389-1391. doi:10.2105/ajph.88.9.1389.

30. Pierce, J. P. et al., 2005. Tobacco industry price-subsidizing promotions may overcome the downward pressure of higher prices on initiation of regular smoking. Health Economics, 14(10), pp. 1061-71. doi:10.1002/hec.990.

31. Farrelly, M. C. \& Bray, J. W., 1998. Response to Increases in Cigarette Prices by Race/Ethnicity, Income, and Age Groups United States, 1976-1993. Morbidity and Mortality Weekly Report (MMWR), 47(29), pp. 605-609.

32. Jimenez-Ruiz, J. A. et al., 2008. The impact of taxation on tobacco consumption in Mexico. Tobacco Control, 17(2), pp. 105-110. doi:10.1136/tc.2007.021030.

33. Bombard, J. M., Pederson, L. L., Nelson, D. E. \& Malarcher, A. M., 2007. Are smokers only using cigarettes? Exploring current polytobacco use among an adult population. Addictive Behaviors, Vol. 32, pp. 2411-2419. doi: 10.1016/j.addbeh.2007.04.001.

34. Backinger, C. L. et al., 2008. Use of other tobacco products among U.S. adult cigarette smokers: Prevalence, trends and correlates. Addictive Behaviors, Vol. 33, pp. 472-489.

doi: 10.1016/j.addbeh.2007.10.009.

35. Siahpush, M., McNeill, A., Hammond, D. \& Fong, G. T., 2006. Socioeconomic and country variations in knowledge of health risks of tobacco smoking and toxic constituents of smoke: results from the 2002 International Tobacco Control (ITC) Four Country Survey. Tobacco Control, 15(suppl 3), pp. iii65-iii70. doi: 10.1136/tc.2005.013276.

36. Stehr, M., 2005. Cigarette tax avoidance and evasion. Journal of Health Economics, 24(2), pp. 277-297. doi:10.1016/j.jhealeco.2004.08.005.

37. Morris, D. S. \& Tynan, M. A., 2012. Fiscal and Policy Implication of Selling Pipe Tobacco for Roll-Your-Own Cigarettes in the United States. PLoS ONE, 7(5): e36487. doi: 10.1371/journal.pone.0036487.

38. Guindon, G. E., Driezen, P., Chaloupka, F. J. \& Fong, G. T., 2013. Cigarette tax avoidance and evasion: Findings from the international tobacco control policy evaluation (ITC) project. Tobacco Control, 23(Suppl 1), pp. i13-22.

doi:10.1136/tobaccocontrol-2013-051074.
39. Centers for Disease Control and Prevention, 2012. Consumption of Cigarettes and Combustible Tobacco - United States, 2000-2011. Morbidity and Mortality Weekly Report (MMWR), 61(30), pp. 565569.

40. DeCicca, P., Kenkel, D. \& Liu, F., 2013. Excise Tax Avoidance: The Case of State Cigarette Taxes. Journal of Health Economics, 32(6). doi: 10.1016/j.jhealeco.2013.08.005.

41. Shelley, D. et al., 2007. The $\$ 5$ Man: The Underground Economic Response to a Large Cigarette Tax Increase in New York City. American Journal of Public Health, 97(8), pp. 1483-1488. doi: 10.2105/AJPH.2005.079921.

42. Young, D. et al., 2006. Prevalence and attributes of roll-your-own smokers in the International Tobacco Control (ITC) Four Country Survey. Tobacco Control, 15(suppl III), pp. iii76-iii82. doi: 10.1136/tc.2005.013268.

43. Brownell, K. D. \& Warner, K. E., 2009. The Perils of Ignoring History: Big Tobacco Played Dirty and Millions Died. How Similar Is Big Food? The Milbank Quarterly, 87(1), pp. 259-294.

44. World Health Organization, 2008. Tobacco Industry Interference with Tobacco Control. Available at: http://www.who.int/tobacco/ resources/publications/Tobacco\%20Industry\%20InterferenceFINAL.pdf. (accessed 6 April 2017).

45. Campaign for Tobacco-Free Kids, 2014. Tobacco-Growing States in the USA, Washington, DC: Campaign for Tobacco-Free Kids.

46. Chaloupka, F. J., Cummings, K. M., Morley, C. \& Horan, J., 2002. Tax, price and cigarette smoking: Evidence from the tobacco documents and implications for tobacco company marketing strategies. Tobacco Control, 11(Supplement 1), pp. i62-72. doi:10.1136/tc.11.suppl_1.i62.

47. Federal Trade Commission, 2015. Federal Trade Commission Cigarette Report for 2012. Washington, DC: Federal Trade Commission.

ACKNOWLEDGEMENTS We would like to thank $\mathrm{Dr}$ Arpana Verma, Head of the Division of Population Health, Health Services Research and Primary Care in the Faculty of Biology, Medicine and Health at the University of Manchester, and other staff in the Department who helped in one way or another with the preparation of this article.

CONFLICT OF INTERESTS

The authors have completed and submitted the ICMJE Form for Disclosure of Potential Conflicts of Interest and none were reported.

\section{FUNDING}

This work was performed as part of a dissertation project for an MPH degree at the University of Manchester and no funding was required.

PROVENANCE AND PEER REVIEW

Not commissioned; externally peer reviewed 